\title{
Mercury Measurement
}

National Cancer Institute

\section{Source}

National Cancer Institute. Mercury Measurement. NCI Thesaurus. Code C147393.

The determination of the amount of mercury present in a sample. 